Research article

\title{
ILLEGAL WASTE SITES AS A POTENTIAL MICRO FOCI OF MEDITERRANEAN LEISHMANIASIS: FIRST RECORDS OF PHLEBOTOMINE SAND FLIES (DIPTERA: PSYCHODIDAE) FROM SLOVENIA
}

\author{
IVOVIĆ Vladimir ${ }^{1,2^{*}}$, KALAN Katja ${ }^{1}$, ZUPAN Sara ${ }^{2}$, BUŽAN Elena ${ }^{1,2}$ \\ ${ }^{1}$ Science and Research Centre, University of Primorska, Koper - Capodistria, Slovenia; ${ }^{2}$ Faculty of \\ Mathematics, Natural Sciences and Information Technologies University of Primorska, Koper - \\ Capodistria, Slovenia
}

(Received 31 ${ }^{\text {th }}$ July 2014; Accepted $13^{\text {th }}$ March 2015)

Apart from being against the law, illegal waste dumping also poses a threat to human health and to the environment. Solid and decomposing waste is an ideal breeding ground for a number of rodents, insects, and other vermin that pose a health risk through the spread of infectious diseases. The main objective of this study was to survey disease vectors and rodents for the presence of Leishmania sp. from waste sites along the Istrian Peninsula in Slovenia and Croatia.

During the survey five sandfly (Pblebotomus neglectus, P. perniciosus, P. papatasi, P. mascitii, Sergentomyia minuta) and five rodent species were collected (Rattus rattus, Mus musculus, Apodemus agrarius, A. flavicollis and A. sylvaticus).

Sandflies and rodents were screened using a molecular probe to amplify an approximately $120 \mathrm{bp}$ fragment of the kinetoplast DNA (kDNA) minicircle for the detection of Leishmania sp. parasites. Leishmania infantum DNA was detected in the spleen of one juvenile black rat (R. rattus). Despite few published records on Leshmania sp. infection in black rats, the addition of our record highlights the importance of further investigation into the frequency and distribution of such occurrences so that we may better classify the role of rodents as potential reservoirs of leishmaniasis in the Mediterranean basin.

Key words: Leishmania, Phlebotomine sandflies, Rodents

\section{INTRODUCTION}

The disposal refuse at illegal waste sites, also known as open dumping or midnight dumping, refers to the improper and/or unauthorized disposal of waste, it is a major problem for many communities throughout Europe. Illegal waste sites are found in isolated locations in both rural and urban areas (along roadsides, in wooded areas and even in national parks and other protected areas). For communities in close proximity

Corresponding author: e-mail: ivovic.v@gmail.com 
they have both an environmental and a social impact while also posing potential threats to human health.

Both Slovenia and Croatia have an increasing problem with illegal dumping, it is estimated that there are currently 60,000 illegal waste sites just within Slovenia [1]. Solid and in particular decomposing organic waste discarded at these sites attract rodents, insects, and other vermin. The introduction of the tiger mosquito Aedes albopictus is known to have occurred mainly via the used tire trade and was enhanced by this species ability to quickly adapt to and colonize new territories [2]. The dumping of old tires and household appliances that readily pool water provide ideal habitats for mosquito species in and around human settlements [3].

Rodents are notorious reservoirs for a number of pathogens and can act as both intermediate infected hosts or hosts for arthropod vectors including ticks, fleas and Phlebotomine sandflies [4]. Rodent-borne zoonoses transmitted from rodent hosts to humans are the cause of significant human morbidity and mortality globally, with several thousand cases diagnosed annually in Europe [5].

There are more than 800 described sandfly species, of which about 100 are suspected or confirmed agents of disease transmission in humans, including 42 Pblebotomus species in the Old World [6]. These Diptera are the exclusive vectors of Leishmania sp., the protozoan agent of visceral (VL) and cutaneous leishmaniasis (CL) in both human and mammalian hosts [4]. Leishmania sp. parasites are transmitted from an animal reservoir (rodents, domestic dogs or wild canids) by the bite of the female phlebotomine sandfly [7]. It can be also anthroponotic where the parasite is transmitted from a human host to another mammal species by a sandfly [8]. Phlebotomines are also vectors of other human pathogens such as bacteria Bartonella and phleboviruses [9].

Nevertheless, the greatest impact of sandflies on human health in South East Europe comes from the rural transmission of Leishmania infantum by several Phlebotomus (Larroussius) species. Four Leishmania species are present in the Mediterranean basin, L. infantum is the most common and is a causative agent of cutaneous (CL) and visceral leishmaniasis (VL), which is fatal if untreated [10].

Domestic dogs are considered to be the major reservoir of Leishmania parasites in the Mediterranean, although some other canids, particularly the red fox (Vulpes vulpes), may be involved in the zoonotic cycle [11]. Other mammal species, particularly rodents, have also been recorded with $L$. infantum infection, including $A$. sylvaticus, $R$. rattus, $R$. norvegicus, Meles meles (European badger), Martes martes (European pine marten), Mustela nivalis (Least weasel) and Genetta genetta (Common genet). Their role as reservoirs of leishmaniasis is not yet clearly understood $[8,11]$. It is noteworthy that both European rat species are found to be infected by Leishmania parasites. The ability to transmit infection has been confirmed by xenodiagnosis in black rats suggesting that this species is a likely host [12].

Disposing of organic waste in an improper manner at illegal waste sites around and inside human settlements provides food for sandfly larval instars and shelters for 
adults. In conjunction with the attraction of rodent species to these sites, life cycle of Leishmania sp. parasites could be promoted with consequent impacts upon human health.

In this study, we investigated the potential risk of illegal waste sites for the spread of leishmaniasis by using a DNA probe to detect the presence of these parasites in sandfly and rodent hosts.

\section{MATERIAL AND METHODS}

The study was conducted on the Istrian peninsula, which is the largest region on the Adriatic Sea located in its Northeastern part and includes portions of Croatia, Slovenia and Italy. The climate of the region is Mediterranean and Sub-Mediterranean with dry and warm summers and mild winters. The average annual air temperature along the northern coast is around $14^{\circ} \mathrm{C}$ and $16^{\circ} \mathrm{C}$ in the southern area and islands. It snows very rarely. The entomological and rodent surveys were carried out at selected and marked illegal waste sites along the study area between April 2011 and May 2013 (Figure 1).

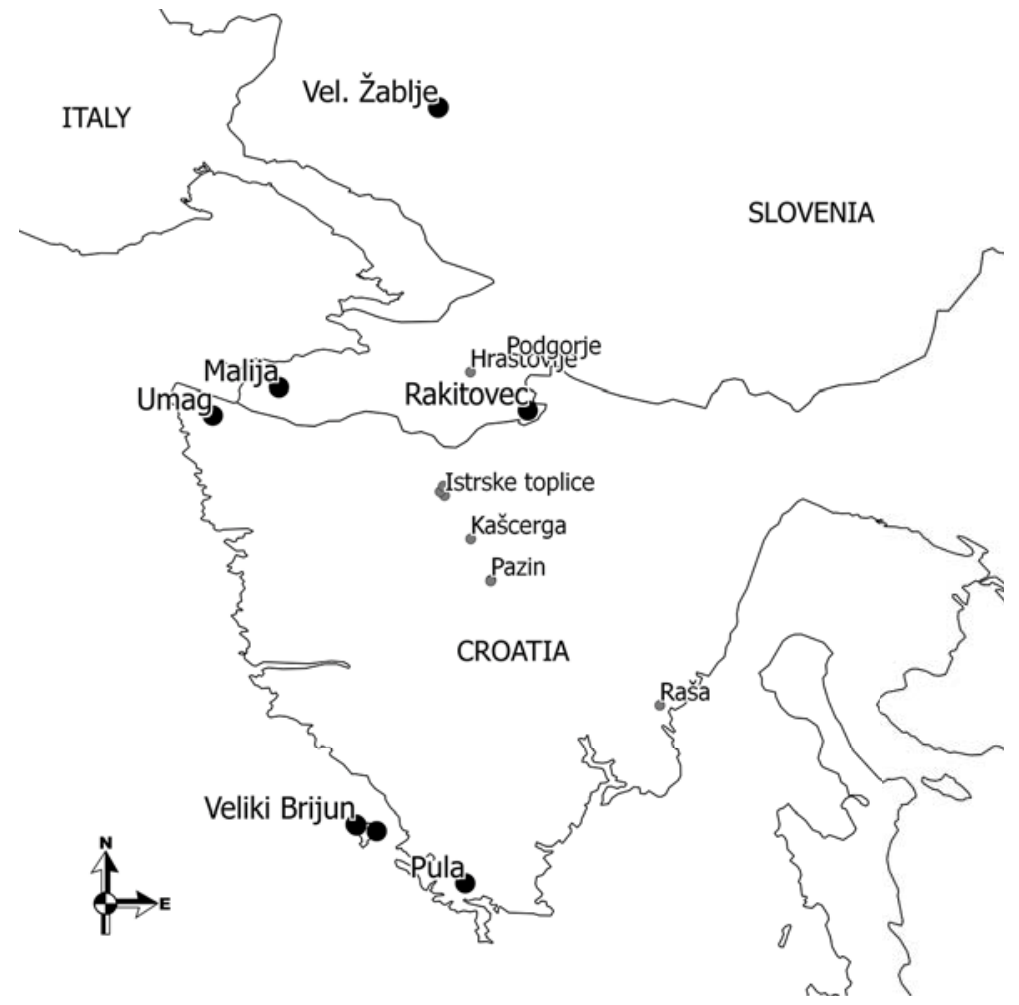

Figure 1. Map of the Istrian peninsula showing locations of investigated illegal waste sites $(\bullet$ positive sandflies sites; $\bullet$ negative sandflies sites) 


\section{Sandflies collection and identification}

Phlebotomine sandflies were collected, both outside and within human settlements, by standard white-light Center for Disease Control and Prevention (CDC) and BGSentinel traps with $\mathrm{CO}_{2}$. Traps were running during, at least three successive nights at various peridomestic, domestic and other locations, near waste sites. The traps were inspected each morning and individual sandflies were separated from other insects and kept either dry or in 70\% ethanol. Indoors, inside houses collection was carried out by mouth or electrically powered aspirators.

Species identification of the Phlebotomine sandflies was based on morphology with the head and terminal part of the abdomen separated and mounted on microscopic slides for inspection [13-16].

\section{Rodents collection and species identification}

All rodents were collected using baited Sherman traps, in order to avoid possible death, injuries and suffering from heat all sampling was conducted from 7:00 pm until early morning hours when they were collected. Species identification was based on morphological characteristics including the color of the fur, ear/tail hair composition and morphometric analysis of the skull and sole as described in the most relevant taxonomic keys $[17,18]$.

\section{Molecular detection of Leishmania parasites}

Genomic DNA was extracted from sandflies using QIAmp DNA Mini Kits (Qiagen, Germany) from the thorax, wings and legs while in rodents spleen tissue was used. All extractions were carried out using the manufacturer's protocols.

Each PCR reaction had a final volume of $25 \mu \mathrm{l}$, and was performed using $3 \mu \mathrm{l}$ of extracted DNA as template, 100 pmol of each of the two primer and KAPA HiFi HotStart ReadyMix 2X (Kapa Biosystems, Inc., United States) containing KAPA dNTPs, reaction buffer and $\mathrm{Mg}^{2+}$ at a $1 \mathrm{X}$ final conc. of $2.5 \mathrm{mM}$ and water. The two primer sequences used in the PCR were 13A 5'-GTGGGGGAGGGGCGTTCT-3' and 13B 5'-ATT'TTCCACCAACCCCCAGTT-3' which amplified a sequence of 120 $\mathrm{bp}$ of the $\mathrm{kDNA}$ minicircles. This conserved sequence is present in all minicircle classes of all Leishmania species and due to its small size the PCR using primers $13 \mathrm{~A} / 13 \mathrm{~B}$ was highly sensitive and suitable for screening. Samples were subjected to the following thermocycling profile: 1 cycle of 3 minutes at $94^{\circ} \mathrm{C}, 30$ cycles of $94^{\circ} \mathrm{C}$ for 30 seconds, 20 seconds at $52^{\circ} \mathrm{C}$ and 15 seconds at $68^{\circ} \mathrm{C}$, with a final extension of 5 minutes at $72^{\circ} \mathrm{C}$. Negative (without DNA) and positive (with DNA) controls were included in all assays. PCR products were analyzed by gel electrophoresis in $2 \%$ agarose gel containing Midori Green DNA Stain (Nipon Genetics Europe GmbH) [19]. 


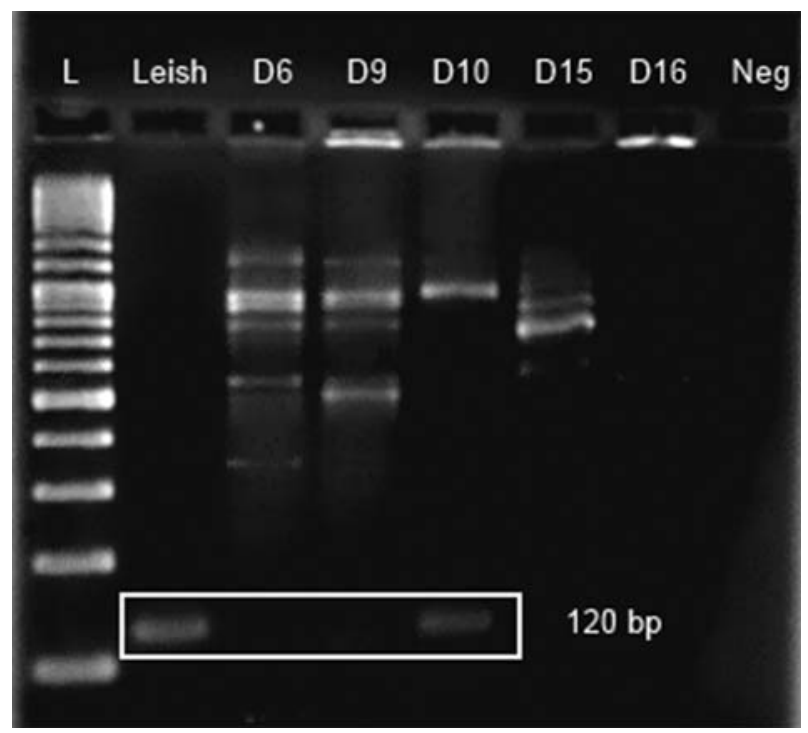

Figure 2. A positive PCR result for the amplified $120 \mathrm{bp}$ Leishmania kDNA minicircles fragment; L) ladder, Leish) positive control, D10) positive sample, Neg) negative control.

Independent verification was carried out on the spleen tissue that tested positive by the Parasitology French Reference Centre on Leishmaniasis, University of Montpellier in France. This organization performed additional molecular analyses that identified the infective agent as L. infantum.

\section{DISCUSSION}

Illegal waste sites have gone from being viewed primarily as an aesthetic problem to a broader environmental issue with wide ranging public health concerns. Although illegally dumped waste is mostly construction and demolition waste, abandoned automobile parts and various appliances, it may also include household trash that contains food scraps and other organic material. Locations where the latter have been dumped make them an ideal for various kinds of vermin.

Phlebotomine sandflies display various resting and breeding habitat preferences in the Mediterranean area. Generally, these are traditional stone walls (or so-called “barbacanes"), rock crevices, tree trunks, caves, wells and rocks [20,21]. However, it has been demonstrated that animal burrows, particularly those of rodents, are a preferred habitat of Old World sandflies [22-24]. In Mediterranean countries several rodent species are involved in the life cycle of the most prevalent Leishmania sp. parasites (L. infantum and L. tropica), the most common of which are Psammomys obesus, Meriones sp. and Rhombomys opimus. Additional species of emerging concern include Microtus guentheri and $M$. tristrami $[25,26]$. 
Although the European rat species $R$. rattus and $R$. norvegicus have occasionally been found with Leishmania parasite infections, the role of these two species is yet to be clarified. Detection of amastigotes in spleen smears of $R$. norvegicus has been reported in Ismailia, Egypt. Near Amman (Jordan) the same rat species and one Meriones sp. have also been found with Leishmania infection but no isolations were made [25]. Furthermore, L. infantum was detected in the spleen tissue of one R. norvegicus trapped in Greece using genetic techniques [27].

Rattus rattus is also considered a possible reservoir of L. infantum in Italy and Spain [28]. Five black rats, collected in central Serbia, were reported with Leishmania parasite infection but the parasites were not identified [29]. In the province of Granada (Spain) L. infantum was isolated from R. rattus [25]. A survey carried out in Southern Italy [30] revealed unusually high infection rates in both $R$. rattus (57.5\% serologically positive and $45 \%$ PCR positive, using the same DNA marker as in this study) and R. norvegicus (33.3\% serologically positive). Using the same DNA marker as in latter Italian study we found that the prevalence of Leishmania infection in $R$. rattus was $16.6 \%$ $(1 / 6)$. Other collected rodent species were not positive.

Our study also investigated two most important Leishmania sandfly vectors collected in illegal waste sites $P$. neglectus and $P$. perniciosus, respectively. Both species are linked to rats as possible reservoirs involved in Leishmania parasite transmission in Greece and Italy $[27,28,31]$. The transmission of $L$. infantum to $R$. rattus by $P$. perniciosus has been demonstrated in laboratory experiments, with additional indications that this species of sandfly has an affinity towards dogs and other farm animals [31]. We tested all of the female sandflies for the presence of Leishmania parasites but the results were negative.

Although a large number of studies have already stressed the harmfulness of illegal landfills, our study indicates their possible contribution to the spread of leishmaniasis. We have demonstrated presence of sandfly vectors, Leishmania pathogens and infected rodents as potential reservoirs, in some of the investigated sites. It was expected for sandfly to be found since they are abundant along the Mediterranean cost, but rodents infected by Leishmania infantum is something that should be of our concern. Within current trends of environmental change species migrations are leading to an expansion in the range and density of leishmaniasis vectors and hosts, as a result we may expect the prevalence of this disease to increase.

As a bridge between Eastern and Western populations, the region of Slovenia hosts an unknown number of sandfly species. We have identified five, including $P$. neglectus, $P$. perniciosus and P. papatasi, some of the most important vectors of Leishmania parasites and these are the first published records of Phlebotomine sandflies fauna in this country (Tab. 1). Due to climate variability, environmental transformations and human activity there may be additional species such as P. kandelaki, a proven vector of Leishmania parasites in the Middle East, present in this region. In 2003, the westernmost range of P. kandelakii was in Montenegro [32], while in 2008 it was collected further to the west, 
at the coast of Croatia in Krk Island (Ivović, unpublished data). Although reported as present in the past the status of leishmaniasis as endemic in Slovenia is not confirmed [11].

\section{CONCLUSIONS}

Recent faunistic and epidemiological research has revealed an increased prevalence of autochthonous leishmaniasis in the European human populations. However, there are still many gaps in our understanding of the distribution of the vectors and hosts of this disease, importantly we have not yet established a methodology to map likely leishmaniasis reservoirs. While there has been significant progress towards understanding what the infection risks of Leishmania are further research is required to provide a comprehensive risk framework for the Euro-Mediterranean region to ensure the best possible public health outcomes.

\section{Acknowledgements}

The authors would like to thank Dr Christophe Ravel from French Reference Centre on Leishmaniasis University of Montpellier (France) for his expert contribution to the Leishmania species identification. This study was founded by DIVA project (cofinanced within the IPA CBC Operational Programme SLO-HR 2007-2013). The support of COST Action TD1303 "European Network for Neglected Vectors and Vector-Borne Infections (EURNEGVEC)" is also acknowledged.

\section{REFERENCES}

1. Matos J, Oštir K, Kranjc J: Attractiveness of roads for illegal dumping with regard to regional differences in Slovenia. Acta Geo Slo 2012, 52(2):431-451.

2. European Centre for Disease Prevention and Control 2009. Development of Aedes albopictus risk maps Stockholm: ECDC.

3. European Centre for Disease Prevention and Control 2012. Guidelines for the surveillance of invasive mosquitoes in Europe. Stockholm: ECDC.

4. Desjeux P: The increase in risk factor for leishmaniasis worldwide. Trans R Soc Trop Med Hyg 2001, 95:239-243.

5. Semenza JC, Menne B: Climate Change and Infectious Diseases in Europe. Lancet ID 2009, 9:365-75.

6. Maroli M, Feliciangeli MD, Bichaud L, Charrel RN, Gradoni L: Phlebotomine sandflies and the spreading of leishmaniases and other diseases of public health concern. Med Vet Entomol 2013, 27(2):123-47.

7. Desjeux P: Leishmaniasis: current situation and new perspectives. Comp Immunol Microbiol Infect Dis 2004, 27(5):305-18.

8. Ready PD: Leishmaniasis emergence in Europe. Euro Surveill 2010, 15(10):pii=19505.

9. Depaquit J, Grandadam M, Fouque F, Andry PE, Peyrefitte C: Arthropod-borne viruses transmitted by Phlebotomine sandflies in Europe. Euro Surveill 2010, 15(10): pii=19507. 
10. Antoniou M, Gramiccia M, Molina R, Dvorak V, Volf P: The role of indigenous phlebotomine sandflies and mammals in the spreading of leishmaniasis agents in the Mediterranean region. Euro Surveill 2013, 18(30):pii=20540.

11. Gramiccia M, Gradoni L: The Leishmaniases of Southern Europe. In: Emerging pests and vector-borne diseases in Europe. Ecology and control of vector borne diseases Vol. 1, (Takken W, Knols B, ed.). Wageningen Academic Publishers 2007, pp. 75-95

12. Svobodova M, Votypka J, Nicolas L, Volf P: Leishmania tropica in the black rat (Rattus rattus): persistence and transmission from asymptomatic host to sand fly vector Phlebotomus sergenti. Microb Infect 2003, 5:361-364.

13. Theodor O: Psychodidae-Phlebotominae. In: Die Fliegen der Palaearktischen Region (Linder, E, ed.). E.Schweizerbart'sche Verlagsbuchhandlung, Stuttgart, Germany 1958, 9c:pp. 55.

14. Perfiliev PP: Fauna of USSR. Diptera. Phlebotomidae (Sand flies). Academy of Science, USSR 1966, Vol. III, No. 2:pp. 383.

15. Lewis DJ: A taxonomic review of the genus Phlebotomus (Diptera, Psychodidae). Bulletin of the British Museum (Natural History). Entomology Series 1982, 2:171-209.

16. Artemiev MM, Neronov VM: Distribution and ecology of sandflies of the Old World (genus Phlebotomus). Institute of Evolutionary morphology and animal ecology. USSR Academy of Sciences, Moscow 1984, pp. 207.

17. Kryštufek B, Janžekovič F: Key for determination of vertebrates of Slovenia. 1st ed. DZS Ljubljana 1999, pp. 544.

18. MacDonald D, Barrett P: Mammals of Britain and Europe (Collins Field Guide), 5th ed. HarperCollins Pub. Ltd. London 1999, pp. 312.

19. Rodgers MR, Stephen J, Wirth DF: Amplification and diagnosis of Leishmania. Exp Parasitol 1990, 71:267-275.

20. Lane RP: Sandflies (Phlebotominae). In: Medical insects and arachnids (Lane RP, Crosskey RW, ed.). Chapman \& Hall, British museum (Natural History), London, UK, 1993, pp.78119.

21. Rioux JA, Carron S, Dereure J, Périéres J, Zeraia L, Franquet E, Babinot M, Gállego M, Prudhomme J: Ecology of leishmaniasis in the South of France. 22. Reliability and representativeness of 12 Phlebotomus ariasi, P. perniciosus and Sergentomyia minuta (Diptera: Psychodidae) sampling stations in Vallespir (eastern French Pyrenees region). Parasite 2013, 20:34.

22. Petrisceva PA: The natural focality of leishmaniasis in the USSR. Bull. WHO 1971, 44(4):567-76.

23. Tabbabi A, Ghrab J, Aoun K, Ready PD, Bouratbine A: Habitats of the sandfly vectors of Leishmania tropica and L. major in a mixed focus of cutaneous leishmaniasis in southeast Tunisia. Acta Trop 2011, 119(2-3):131-7.

24. Parvizi P, Alaeenovin E, Kazerooni PA, Ready PD: Low diversity of Leishmania parasites in sandflies and the absence of the great gerbil in foci of zoonotic cutaneous leishmaniasis in Fars province, southern Iran. Trans R Soc Trop Med Hyg 2013, 107(6):356-62.

25. Desjeux P: Information on the epidemiology and control of the leishmaniases by country or territory. WHO/LEISH/91.301991.

26. Faiman R, Abbasi I, Jaffe C, Motro Y, Nasereddin A, Schnur LF, Torem M, Pratlong F, Dedet JP, Warburg A: A newly emerged cutaneous leishmaniasis focus in northern Israel and two new reservoir hosts of Leishmania major. PLoS Negl Trop Dis 2013, 7(2): e2058. 
27. Papadogiannakis E, Spanakos G, Kontos V, Menounos PG, Tegos N, Vakalis N: Molecular detection of Leishmania infantum in wild rodents (Rattus norvegicus) in Greece. Zoon Pub Health 2010, 57(7-8):e23-5.

28. Gradoni L, Pozio E, Gramiccia M, Maroli M, Bettini S: Leishmaniasis in Tuscany (Italy): VII. Studies on the role of the black rat (Rattus rattus), in the epidemiology of visceral leishmaniasis. Trans R Soc Trop Med Hyg 1983, 77:427-431.

29. Petrović Z, Bordjoski A, Savin Z: Les resultas de recherches sur le reservoir de Leishmania donovani dans une region endemique du Kala-azar. Proceedings of the Second European Multicolloquy of Parasitology, Trogir, Croatia 1975, 2:97-98.

30. Di Bella C, Vitale F, Russo G, Greco A, Milazzo C, Aloise G, Cagnin M: Are rodents a potential reservoir for Leishmania infantum in Italy? J Mt Ecol 2003, 7(suppl.):125-129.

31. Pozio E, Maroli M, Gradoni L, Gramiccia M: Laboratory transmission of Leishmania infantum to Rattus rattus by the bite of experimentally infected Phlebotomus perniciosus. Trans R Soc Trop Med Hyg 1985, 79(4):524-6.

32. Ivović V, Depaquit J, Léger N, Urano A, Papadopoulos B: Sandflies (Diptera: Psychodidae) in the Bar area of Montenegro (Yugoslavia). 2. Presence of promastigotes in Phlebotomus neglectus and first record of P. kandelakii. Ann Trop Med Parasitol 2004, 98(4):425-427.

\title{
DIVLJE DEPONIJE KAO POTENCIJALNA ŽARIŠTA LAJŠMANIOZE NA PODRUČJU MEDITERANA: PRVI NALAZ FLEBOTOMINA (DIPTERA: PSYCHODIDAE) U SLOVENIJI
}

\author{
IVOVIĆ Vladimir ${ }^{1,2^{*}}$, KALAN Katja ${ }^{1}$, ZUPAN Sara ${ }^{2}$, BUŽAN V Elena
}

Osim što je protivzakonito, ilegalno odlaganje odpada predstavlja pretnju kako za ljudsko zdravlje tako i za životnu sredinu. Takođe, čvrst a posebno organski otpad u stanju truljenja, predstavlja idealno mesto za razmnožavanje i razvoj brojnih glodara, insekata, i drugih štetočina koje mogu da šire zarazne bolesti. Glavni cilj ove studije bio je utvrđivanje stepena inficiranosti parazitom iz roda Leishmania sp., flebotomina kao vektora i glodara kao rezervoara koji su sakupljeni na ilegalnim deponijama u delu Istarskog poluostrva.

Rezultati istrživanja su ukazali na prisustvo pet vrsta flebotomina (Phlebotomus neglectus, P. perniciosus, P. papatasi, P. mascitii i Sergentomyia minuta) i pet vrsta glodara.

Sakupljene flebotomine i glodari su testirani molekularno-biološkom metodom PCR (lančana reakcija polimerizacije) kojom je umnožavan region od oko 120 baznih parova kDNK (kinetoplast DNA minicircle) parazitskog porekla. DNK vrste L. infantum nije detektovana u analiziranim ženkama flebotomina ali je detektovana u uzorku slezine jednog od juvenilnih crnih pacova (R. rattus).

Bez obzira na mali broj publikovanih nalaza koji ukazuju na prisustvo parazita Leishmania sp. kod pacova, rezultat ove studije ukazuje na značaj obimnijih istraživanja učestalosti i distribucije infekcije kod ove vrste glodara, na osnovu kojih bi se razjasnila uloga sinantropnih glodara kao rezervoara lajšmanioze u Mediteranu. 